\title{
Development and Demonstration of Six-Dimensional Muon Beam Cooling (Same)
}

\section{Cooperative Research and Development Agreement Final Report}

\section{CRADA Number: FRA-2007-0004}

\section{Fermilab Technical Contact: Vladmir Shiltsev}

Summary Report

06 January 2020 


\section{NOTICE}

This report was prepared as an account of work sponsored by an agency of the United States government. Neither the United States government nor any agency thereof, nor any of their employees, makes any warranty, express or implied, or assumes any legal liability or responsibility for the accuracy, completeness, or usefulness of any information, apparatus, product, or process disclosed, or represents that its use would not infringe privately owned rights. Reference herein to any specific commercial product, process, or service by trade name, trademark, manufacturer, or otherwise does not necessarily constitute or imply its endorsement, recommendation, or favoring by the United States government or any agency thereof. The views and opinions of authors expressed herein do not necessarily state or reflect those of the United States government or any agency thereof.

Available electronically at http://www.osti.gov/bridge

Available for a processing fee to U.S. Department of Energy and its contractors, in paper, from:

U.S. Department of Energy Office of Scientific and Technical Information

P.O. Box 62

Oak Ridge, TN 37831-0062

phone: 865.576 .8401

fax: 865.576 .5728

email: mailto:reports@adonis.osti.gov

Available for sale to the public, in paper, from:

U.S. Department of Commerce

National Technical Information Service

5285 Port Royal Road

Springfield, VA 22161

phone: 800.553 .6847

fax: 703.605.6900

email: orders@ntis.fedworld.gov

online ordering: http://www.ntis.gov/ordering.htm 
In accordance with Requirements set forth in Article XI.A(3) of the CRADA document, this document is the final CRADA report, including a list of Subject Inventions, to be forwarded to the Office of Science and Technical Information as part of the commitment to the public to demonstrate results of federally funded research.

CRADA number: $\quad$ FRA-2007-0004

CRADA Title: $\quad$ Development and Demonstration of Six-Dimensional Muon Beam Cooling (Same)

Parties to the Agreement: Muons, Inc. and Fermi Research Alliance, LLC

\begin{abstract}
CRADA work:
Ionization cooling, a method for shrinking the size of a particle beam, is an essential technique for the use of muons in future particle accelerators. Muon colliders and neutrino factories, examples of such future accelerators, depend on the development of robust and affordable ionization cooling technologies. A 6D cooling experiment has been proposed, incorporating a novel configuration of helical and solenoidal magnets in a prototype cooling channel. This Helical Cooling Channel (HCC) experiment is being designed to provide an affordable and striking demonstration that 6D muon beam cooling is understood well enough to enable intense neutrino factories and high-luminosity muon colliders. Because of the large amount of expected beam cooling, helium instead of hydrogen can be used for the initial experiment, avoiding the safety complications of hydrogen. The main points of the experiment are described, and corresponding numerical simulations are reviewed.
\end{abstract}

\title{
Summary of Research Results:
}

Summary of accomplishments and project activities are as follows:

1. Helical Cooling Channel (HCC) magnet design progressed in considerable detail.

2. HCC four-coil test: The magnet reached 85 percent of short sample, the approximate level of design operation. It also reached a considerably higher current than the design current, albeit in a lower field. The field distributions agree well with predictions.

3. Several approaches to integrating the RF into the helical magnet were investigated.

4. Placement of the experiment in the MICE hall at Rutherford-Appleton Lab was explored.

5. Investigated the integration and matching of the MANX magnet with the MICE spectrometers and their magnets.

6. The MANX collaboration was formed, held a meeting, and submitted the MANX proposal to the Fermilab AAC. 
7. Twelve conference posters and papers were prepared and presented, demonstrating progress and attracting new collaborators.

Related Reports, Publications, and Presentations:

1. Final Technical Report on STTR Project DE-FG02-06ER86282, “Development and Demonstration of 6-Dimensional Muon Beam Cooling", Muons Inc.

https://www.osti.gov/servlets/purl/1015012

Subject Inventions listing:

None

Report Date: 06 January 2020

Technical Contact at Fermilab: Vladmir Shiltsev

This document contains NO confidential, protectable or proprietary information. 